\title{
Metabolizable energy and digestible amino acids of full-fat soybean without or with protease supplementation in diets for broilers
}

\author{
Energia metabolizável e aminoácidos digestíveis da soja integral sem ou com a \\ suplementação de protease em rações para frangos de corte
}

\author{
Felipe Santos Dalólio ${ }^{1 *}$, Luiz Fernando Teixeira Albino², Horácio Santiago Rostagno², \\ Diego Ladeira da Silva², Maurílio de Lucas Xavier Júnior², Vinícius Duarte de Oliveira ${ }^{2}$
}

\author{
${ }^{1}$ Universidade Federal de Viçosa/UFV, Departamento de Engenharia Agrícola, Viçosa, MG, Brazil \\ ${ }^{2}$ Universidade Federal de Viçosa/UFV, Departamento de Zootecnia, Viçosa, MG, Brazil \\ *Corresponding author: felipesantos181@hotmail.com \\ Received in December 16, 2015 and approved in June 27, 2016
}

\begin{abstract}
Two experiments were carried out to determine the energy values and the true ileal digestibility of amino acids of nine toasted full-fat soybeans (FFSB), without or with the addition of monocomponent protease. In the first experiment, to determine the energy values, the method of excreta collection was used with 1120 broiler chicks at 14 days old, distributed in randomized blocks in a 10x2 factorial arrangement with nine full-fat soybeans (30\% included) plus a control diet (70\%) without or with the addition of protease, totaling 20 treatments with 8 replicates and 7 birds per cage. In the second experiment, 1120 broiler chickens from 24 to 28 days of age were distributed in randomized blocks in a 10x2 factor arrangement, with nine full-fat soybeans ( $40 \%$ included) + a protein free diet (60\%), without or with the addition of protease, totaling 20 treatments with 8 replicates and 7 birds per cage. lleal digesta collection was used to determine the true digestibility coefficients and the digestible amino acid content of full-fat soybean. The average values of nitrogen-corrected apparent metabolizable energy (AMEn) and their respective metabolization coefficients (CAMEn) were $3207 \mathrm{kcal} / \mathrm{kg}$ and 62.57\%, respectively. The average values of digestibility coefficients of crude protein and essential and nonessential amino acids were $86.79,87.90$ and $84.34 \%$, respectively. The inclusion of protease improved $(P<0.05)$ all evaluated parameters. Therefore, its use is recommended in diets containing full-fat soybeans for broiler chickens.
\end{abstract}

Index terms: Digestibility coefficients; metabolizability; monocomponent enzyme.

\begin{abstract}
RESUMO
Foram realizados dois experimentos para determinar os valores energéticos e os coeficientes de digestibilidade ileal verdadeiros de aminoácidos de nove sojas integrais tostadas, sem ou com a adição de protease monocomponente. No primeiro experimento, para a determinação dos valores energéticos, foi utilizado o método de coleta total de excretas, com 1120 pintos de corte com 14 dias de idade, distribuídos em blocos casualizados, em arranjo fatorial 10×2, com nove sojas integrais (30\% de inclusão) + uma ração referência (70\%), sem ou com adição de protease, totalizando 20 tratamentos, com 8 repetições e 7 aves por gaiola. No segundo experimento foram utilizados 1120 frangos dos 24 aos 28 dias de idade, distribuídos em blocos casualizados, em arranjo fatorial 10x2, com nove sojas integrais (40\% de inclusão) + uma ração isenta de proteína (60\%), sem ou com adição de protease, totalizando 20 tratamentos, com 8 repetições e 7 aves por gaiola. A coleta da digesta ileal foi utilizada para determinar os coeficientes de digestibilidade verdadeiros e o teor de aminoácidos digestíveis da soja integral. Os valores médios de energia metabolizável aparente corrigida para balanço de nitrogênio (EMAn) e o seu respectivo coeficiente de metabolizabilidade (CEMAn) foram de $3207 \mathrm{kcal} / \mathrm{kg}$ e 62,57\%, respectivamente. Os valores médios dos coeficientes de digestibilidade da proteína bruta e dos aminoácidos, essenciais e não essenciais foram de 86,79, 87,90 e 84,34\%, respectivamente. A inclusão de protease melhorou $(P<0,05)$ todos os parâmetros avaliados. Portanto, recomenda-se sua utilização em rações formuladas com soja integral para frangos de corte.
\end{abstract}

Termos para indexação: Coeficientes de digestibilidade; metabolizabilidade; enzima monocomponente.

\section{INTRODUCTION}

For a better utilization of the diets by the animals, besides the chemical and energy composition, the knowledge of the concentration of digestible amino acids (AA) is important, since the amino acids that make up the protein of the feed are not completely available for the animal (Gomes et al., 2010). Therefore, it is necessary to determine the digestibility coefficients of the AA in certain feeds, aiming at obtaining the values of digestible AA. This enables the formulation of more effective and accurate diets and reduces negative impact of environmental pollution. It also leads a cost reduction since protein is one of the most expensive ingredients. 
Soybean meal is the main protein source added to the diets. This is more evident in broilers farming, which requires more dense diets with adequate balance of digestible AA. However, the intense use of soybean meal causes the poultry sector to depend on it, raising the production costs (Ncobela; Chimonyo, 2015). Therefore, the search for new protein feeds that can replace partially or completely soybean meal in diet formulation is needed.

Full-fat soybean (FFSB) presents about 36\% of crude protein $(\mathrm{CP})$ and $18 \%$ of ether extract (EE) (Rostagno et al., 2011), wich is an excellent alternative to soybean meal and to the inclusion of vegetable oil (Costa et al., 2015). Moreover, the digestibility of AA, $\mathrm{EE}$ and metabolizable energy of the FFSB is similar to the conventional soybean meal and vegetable oil mixture (Café et al., 2000), commonly used to enhance energy levels and dietary AA contents.

However, the presence of some antinutritional factors in FFSB, such as protease inhibitors (particularly trypsin and chymotrypsin), lectins, allergenic proteins, saponins, protein-protein interaction as well as the Mailard reaction at the thermal processing of fresh grain, change the use of nutrients by broilers and limit their use in diet formulation (Valencia et al., 2009; Rocha et al., 2014).

According to Carvalho et al. (2008) the high temperatures inactivates the antinutritional factors of soybean, allowing its use in the whole form. However, toasting may not be sufficient to inactivate all the antinutritional factors and may damage pancreatic enzymes, such as trypsin, in broiler chickens (Clarke; Wiseman et al., 2005).

The use of exogenous enzymes, especially proteases, has been successfully evaluated (Yu et al., 2007; Angel et al., 2011) to improve the availability of nutrients and the supplementation endogenous enzymes. It reduces the problem of incomplete standardization in thermal process. Also, the addition of protease in diets for broilers promotes increase in the digestibility of CP and AA (Freitas et al., 2011). Moreover, the supplementation with proteases provides larger degradation of conglycinin and $\beta$-conglycinin present in raw soybeans (Graham et al., 2002); both considered allergenic proteins (Zilic et al., 2011).

Thus, the objective of this study was to evaluate the values of nitrogen-correted apparent metabolizable energy, digestible amino acids, and their respective coefficients of digestibility of full-fat soybean samples without or with the addition of protease in diets for broilers.

\section{MATERIAL AND METHODS}

All procedures using animals for research were approved by the ethics committee for experimentation and use of animals in research at UFV, under protocol 043/2015.

Two biological trials were carried out in the Poultry Sector in the Animal Science Department of the Universidade Federal de Viçosa. In the first trial, 1120 male Cobb 500 broiler chicks at 14 days of age with average weight of $440.0 \pm 5.0 \mathrm{~g}$ were used. From birth to 13 days of age, the broilers were raised in brick shed with floor covered with wood shavings, where they received proper diet for the initial period, following the recommendations of Rostagno et al. (2011).

At 14 days of age, the broilers were transferred to metal batteries (cages) provided with platform type feeder, nipple drinker and a plastic covered tray for excreta collection. The experimental design used was a complete randomized blocks in a $10 \times 2$ factor arrangement (a control basal diet and nine samples of toasted FFSB, without and with the addition of protease), totaling 20 treatments and eight replicates with seven birds per experimental unit. The product used has 75.000 protease units/ $g$ of enzyme, and diets were provided as "on top" without their respective nutritional value at the proportion of $200 \mathrm{ppm}$ (15.000) according to the recommendations of the manufacturer. This protease is manufactured from the fermentation of Bacillus lincheniformis containing gene transcripted Nocardiopsis prasina, being considered as monocomponent protease. The enzymatic activity for this enzyme is defined as the amount of enzyme needed to degrade $1 \mu \mathrm{mol}$ of the substrate (Suc-Ala-Ala-Pro-Phe-N-succinyl Ala-Ala-Pro-Phe-pnitroanilide) per minute in $\mathrm{pH}$ of 9.0 at $37^{\circ} \mathrm{C}$.

The basal diet was formulated according to the recommendations of Rostagno et al. (2011) (Table 1). The experimental diets were composed of $70 \%$ of the reference basal diet and $30 \%$ of inclusion of each sample of toasted FFSB to be evaluated for each treatment, without or with the addition of protease. Broilers were fed diets ad libitum. Samples of toasted FFSB were from nine feed mills (Samples 1 to 9), belonging to the same grain producer company. The thermal process used been for toasting rotating drum. In this process the whole soybean enters a tube which is subjected to a dry air stream. Reaching a temperature of $120-125^{\circ} \mathrm{C}$ in tosting machine output.

The experiment lasted 10 days with 5 days for adaptation and 5 days for total excreta collection. The total excreta collection were carried out daily and then, the samples were placed in a freezer at a temperature of $-20{ }^{\circ} \mathrm{C}$ to prevent bacterial fermentation. Samples were weighed, homogenized and representative sub-samples 
were taken for pre-drying at $55^{\circ} \mathrm{C}$ in a forced ventilation oven for 72 hours for subsequent determination of values of dry matter (DM), CP and nitrogen $(\mathrm{N})$, according to the methodology proposed by Silva and Queiroz (2002).

For determining the content of DM, N, CP, crude fiber (CF) and EE of samples of FFSB, the methodology proposed by Silva and Queiroz (2002) was used. Analyzes of urease index, protein solubility, and trypsin inhibitor were carried out in soybean samples according to Associação Nacional dos Fabricantes de Rações - ANFAR (2005). Based on the results achieved for $\mathrm{N}$ and gross energy (GE) of the diets and excreta, determined in the Parr-1261 bomb calorimeter, values

Table 1: Composition of experimental diets used for the determination of metabolizable energy values and content of digestible amino acids of full-fat soybean samples.

\begin{tabular}{|c|c|c|c|}
\hline Diet reference basal ${ }^{1}$ & \multirow{2}{*}{$(\%)$} & $\mathrm{PFD}^{2}$ & \multirow{2}{*}{$(\%)$} \\
\hline Ingredients & & Ingredients & \\
\hline Corn & 72.466 & Starch & 80.310 \\
\hline Soybean meal & 22.368 & Sugar & 5.000 \\
\hline Soy oil & 1.000 & Soy oil & 5.000 \\
\hline Dicalcium phosphate & 1.609 & Dicalcium phosphate & 2.100 \\
\hline Limestone & 0.926 & Limestone & 0.700 \\
\hline Salt & 0.481 & Salt & 0.450 \\
\hline DL-methionine (99\%) & 0.146 & Potassium carbonate & 1.000 \\
\hline L-lysine HCl (78\%) & 0.168 & Corn cob & 4.000 \\
\hline L-threonine (98\%) & 0.001 & Vitamin Supplement ${ }^{3}$ & 0.080 \\
\hline Vitamin Supplement ${ }^{3}$ & 0.110 & Mineral Supplement ${ }^{4}$ & 0.150 \\
\hline Mineral Supplement ${ }^{4}$ & 0.010 & Choline chloride (60\%) & 0.200 \\
\hline Choline chloride (60\%) & 0.100 & Antioxidant ${ }^{6}$ & 0.010 \\
\hline Anticoccidial ${ }^{5}$ & 0.055 & Acid insoluble ash (CeliteTM) & 1.000 \\
\hline Antioxidant ${ }^{6}$ & 0.010 & Total & 100.000 \\
\hline Total & 100.000 & Composition analyzed basal diet reference & \\
\hline Calculated composition & & Gross energy & 3902 \\
\hline Metabolizble Energy (Kcal/kg) & 3050 & Metabolizable Energy (Kcal/kg) & 3035 \\
\hline Crude protein (\%) & 16.132 & Crude protein (\%) & 16.35 \\
\hline Digestible lysine (\%) & 0.847 & - & - \\
\hline Digestible methionine (\%) & 0.395 & - & - \\
\hline Digestible Met + Cist (\%) & 0.610 & - & - \\
\hline Digestible threonine (\%) & 0.550 & - & - \\
\hline Digestible tryptophan (\%) & 0.166 & - & - \\
\hline Calcium (\%) & 0.819 & - & - \\
\hline Non-phytate phosphorus (\%) & 0.391 & - & - \\
\hline Sodium (\%) & 0.210 & - & - \\
\hline
\end{tabular}

${ }^{1}$ Diet reference used to evaluate the metabolizable energy values of nine samples of FFSB. ${ }^{2}$ FPD: Protein free diet, used to evaluate the true digestibility of amino acids in nine samples of FFSB. ${ }^{3}$ Composition for kg of product: manganese, $75.000 \mathrm{mg}$; iron, 20000 mg; zinc, $50.000 \mathrm{mg}$; copper, $4.000 \mathrm{mg}$; cobalt, $200 \mathrm{mg}$; iodine $1.500 \mathrm{mg}$ and qsp, $1.000 \mathrm{~g}$. ${ }^{4}$ Composition for kg of product: vit. A, 12.000.000 Ul; vit. D3, 2.200.000 Ul; vit. E 30.000 Ul; vit. B1, 2.200 mg; vit B2, 6.000 mg; vit. B6, 3.300mg; pantothenic acid,

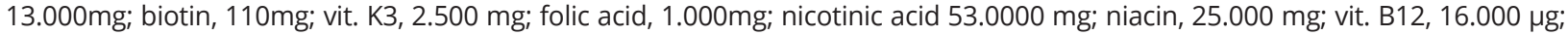
selenium, $0.25 \mathrm{~g}$ and qsp., 1.000g. ${ }^{5}$ Salinomycin $12 \% .{ }^{6}$ Butyl Hydroxy Toluene. 
of nitrogen-corrected apparent metabolizable energy (AMEn) were estimated using the equations proposed by Matterson et al. (1965). After that, the metabolization coefficients of the nitrogen-corrected apparent energy (CAMEn) were set.

In the second trial, 1120 male Cobb 500 broilers were 24 days old and an average weight of $890.00 \pm 10.0 \mathrm{~g}$ were used. Broilers were distributed in randomized blocks in a $10 \times 2$ factor arrangement (nine FFSB - 40\% included + a protein free diet (PFD) - $60 \%$, without or with the addition of monocomponent protease) (Table 1), totaling 20 treatments and eight replicates with seven birds each. Celite ${ }^{\mathrm{TM}}$ acidinsoluble ash was added at $1 \%$ into all experimental diets. The enzyme used in the experiment, its respective characteristics and proportion of inclusion were above cited in the first trial. Until the $23^{\text {rd }}$ day, the animals were raised fed basal diet following the recommendations of Rostagno et al. (2011). Subsequently, the broilers were sheltered in batteries from the $24^{\text {th }}$ day to the $28^{\text {th }}$ day of age, fed the experimental diets.

After a $4^{\text {th }}$ day adaptation period, the broilers were slaughtered by electronarcosis for collection of ileal digesta. Then, broilers were opened in the abdominal cavity, removing the entire intestinal content, which was $40 \mathrm{~cm}$ from the terminal ileum portion prior to the ileocecal junction. Before slaughter, the broilers were encouraged to consume feed to prevent the emptying of the digestive tract, which affects the ileal digesta collection procedure.

Samples of ileal digesta were freeze-dried under vacuum, at a temperature of $-40{ }^{\circ} \mathrm{C}$ for 72 hours, and laboratory analyses were carried out to verify the amino acidic content by HPLC (High Performance Liquid Chromatography), according to the methodology described by Association of Official Agricultural Chemists -
AOAC (1995). Dry matter and CP of digesta were also determined according to Silva and Queiroz (2002). The acid-insoluble ash and indigestible factor were carried out according to Joslyn (1970). The calculations of the true ileal digestibility of amino acids were performed using the methodology proposed by Sakomura and Rostagno (2007).

Dataset for the first and second experiments were submitted to analysis of variance (ANOVA), and means were analyzed by Student-Newman-Keulls (SNK) test at $5 \%$. All analyzes were carried out using the Statistical and Genetics Analysis System software - UFV (SAEG, 2007).

\section{RESULTS AND DISCUSSION}

From the chemical composition of toasted FFSB samples, it can be inferred that this feed presents a good profile of CP and EE in addition to reduced CF content (Table 2). These results corroborate the findings by Rostagno et al. (2011) and Ravindran et al. (2014). The GE sample values of FFSB of the present study were higher than those found by Rostagno et al. (2011), of $5032 \mathrm{kcal} / \mathrm{kg}$, except for the sample 4. This occurred due to the lower EE content in this sample.

The concentration of trypsin inhibitor factor in samples 4 and 5 were over the acceptable limit of 4.1 TIF $\mathrm{mg} / \mathrm{g}$, for the FFSB (Ravindran et al., 2014). The urease index on samples 4 and 5 were over than the range $(0.03$ to 0.05) recommended by Araba and Dale (1990). However, the protein solubility values of all samples ranged between 70 and $85 \%$, as recommended by Parsons et al. (1991). According to Nunes et al. (2015) the evaluation the effectiveness of the termal treatment used to deactivate anitinutritional factors in FFSB, correlates urease index

Table 2: Chemical composition (\% natural matter), protein solubility (\%), urease index and trypsin inhibitor factor of samples of toasted full-fat soybeans.

\begin{tabular}{crrrrrrrrr}
\hline \multirow{2}{*}{ Analysis } & \multicolumn{10}{c}{ Toasted full-fat soybean samples } \\
\cline { 2 - 10 } & \multicolumn{1}{c}{ 1 } & \multicolumn{1}{c}{ 2 } & \multicolumn{1}{c}{4} & \multicolumn{1}{c}{5} & \multicolumn{1}{c}{6} & 7 & 8 & 9 \\
\hline GE (kcal/kg) & 5173 & 5099 & 5237 & 4646 & 5307 & 5216 & 5216 & 5108 & 5190 \\
DM (\%) & 90.86 & 91.05 & 90.97 & 90.78 & 90.83 & 90.91 & 90.98 & 90.90 & 90.88 \\
CP (\%) & 34.96 & 36.87 & 37.81 & 39.77 & 35.58 & 34.59 & 38.93 & 36.23 & 36.84 \\
EE (\%) & 21.71 & 20.71 & 20.39 & 10.25 & 22.09 & 20.86 & 19.98 & 20.94 & 21.82 \\
CF (\%) & 4.73 & 3.57 & 2.45 & 4.93 & 4.90 & 3.75 & 2.90 & 3.72 & 4.76 \\
PS (\%) & 74.99 & 73.52 & 74.53 & 84.10 & 72.68 & 74.19 & 83.10 & 73.75 & 76.90 \\
UI (pH) & 0.05 & 0.05 & 0.05 & 0.11 & 0.36 & 0.05 & 0.05 & 0.05 & 0.05 \\
TIF (mg/g) & 1.63 & 1.15 & 1.40 & 8.96 & 4.38 & 1.54 & 1.12 & 1.30 & 1.90 \\
\hline GE = gross energy; DM = dry matter; CP = crude protein; EE = ether extract; CF = crude fiber; PS = protein solubility KOH (0.2\%); \\
UI = urease index in units of pH; TIF = Trypsin inhibitor factor (TIFmg/g of protein).
\end{tabular}


and protein solubility. Since, high values of urease index indicate sub-haeting within the same type of processing.

In this study it was observed that there is variation among the FFSB samples. The discrepancy between the chemical composition data and the FFSB can occur due to type of processing, type of cultivar used, type of planting, and the place of origin (Valencia et al., 2009). According to Freitas et al. (2005) for the same type of processing there is no complete standardization of conditions of temperature, humidity, time and pressure. Therefore, we can infer that the toasted FFSB samples had no standardization among the various production units.

The nitrogen-corrected apparent metabolizable energy (AMEn) of FFSB samples, without addition of protease, were similar to those reported by Ravindran et al. (2014), by $3228 \mathrm{kcal} / \mathrm{kg}$ and lower than those reported by Valencia et al. (2009) and Rostagno et al. (2011), by 3439 and 3463 $\mathrm{kcal} / \mathrm{kg}$, respectively (Table 3).

Among the analyzed samples, the $\mathrm{CP}$ and $\mathrm{EE}$ of FFSB sample 4 showed greater variability. Acoording to

Table 3: Nitrogen-corrected apparent metabolizable energy (AMEn) values and their respective metabolization coefficient (CEMAn) of toasted full-fat soybean samples without and with addition of protease expressed in natural matter $(\mathrm{kcal} / \mathrm{kg})$, for the first experiment.

\begin{tabular}{|c|c|c|c|}
\hline FFSB & Enzyme & $\mathrm{AME}_{\mathrm{n}}$ & CAME $_{n}$ \\
\hline \multirow{2}{*}{ Sample 1} & without & 3063 & 59.22 \\
\hline & with & 3243 & 62.68 \\
\hline \multirow{2}{*}{ Sample 2} & without & 3199 & 62.75 \\
\hline & with & 3438 & 67.43 \\
\hline \multirow{2}{*}{ Sample 3} & without & 3232 & 61.71 \\
\hline & with & 3343 & 63.84 \\
\hline \multirow{2}{*}{ Sample 4} & without & 3220 & 69.52 \\
\hline & with & 3519 & 75.75 \\
\hline \multirow{2}{*}{ Sample 5} & without & 3269 & 61.59 \\
\hline & with & 3343 & 62.99 \\
\hline \multirow{2}{*}{ Sample 6} & without & 3289 & 63.06 \\
\hline & with & 3510 & 67.30 \\
\hline \multirow{2}{*}{ Sample 7} & without & 3060 & 58.66 \\
\hline & with & 3154 & 60.47 \\
\hline \multirow{2}{*}{ Sample 8} & without & 3254 & 63.70 \\
\hline & with & 3388 & 66.32 \\
\hline \multirow{2}{*}{ Sample 9} & without & 3267 & 62.94 \\
\hline & with & 3275 & 63.11 \\
\hline \multirow{2}{*}{ Enzyme } & without & $3207 \mathrm{~b}$ & $62.57 \mathrm{~b}$ \\
\hline & with & $3357 a$ & $65.54 \mathrm{a}$ \\
\hline Diference & & 150 & 2.97 \\
\hline \multirow[t]{2}{*}{$\mathrm{CV}(\%)$} & & 6.94 & 7.08 \\
\hline & & \multicolumn{2}{|c|}{$P$ - value } \\
\hline $\mathrm{FFSB}^{1}$ & & 0.004 & 0.004 \\
\hline$E$ & & 0.002 & 0.002 \\
\hline FFSB $\times E$ & & 0.852 & 0.952 \\
\hline
\end{tabular}

FFSB = full-fat soybeans samples; $\mathrm{E}$ = enzyme; FFSB $\times \mathrm{E}$ = interaction of factors FFSB and E; a-b Different letters in the same column differ by SNK test $(\mathrm{P}<0.05)$; $C V=$ Coefficient of variation. ${ }^{1}$ The marginal mean values of FFSB samples are presented in Table 4. 
Nunes et al. (2005) the factors that most influences the use of energy feedtuffs by broilers are the levels of $\mathrm{CP}$ and $\mathrm{EE}$. This is due to the difference in caloric increment of protein and fat, changing the energy balance for nitrogen excretion and deposition of body tissue. Overall, the protease enhanced values of AMEn and CAMEn compared to those without addition (Table 3). Similar results was observed by Yu et al. (2007), Freitas et al. (2011) and Matias et al. (2015), when they evaluated soybean meal based diets as a protein source, supplemented or not with protease.

The enzymatic activity of protease provided an average of $150 \mathrm{kcal} / \mathrm{kg}$, which is $4.5 \%$ more energy in the FFSB samples evaluated in this study. This indicates better utilization of $\mathrm{CP}$ from the FFSB, providing greater amount of AA available for protein metabolism and other nutrients. By hydrolyzing the reserve proteins of whole soybean grains, protease releases some nutrients, such as starch, promoting the use of energy from the diet (Fru-Nji et al., 2011). Accordingly, protease releases the potential energy contained in the starch-protein bonds, and this effect is more evident in varieties with lower EE, as CP is increased with the dilution effect, as observed in sample 4 (Table 3).

When analyzing the average marginal effect on the type of FFSB in the use of energy, it is clear that the sample 7 was higher than sample $4(\mathrm{P}<0.05)$, however, did not differ from the others.

According to Lemme et al. (2004) a substantial amount of AA and protein passes through the gastrointestinal tract of broilers and are not utilized neither completely digested. Protease supplementation also increases hydrolysis of antinutritional protein-origin factors such as trypsin and lectin inhibitors, enhancing the use efficiency of AA (Ghazi et al., 2002), even as supplied as "on top" (Fru-Nji et al., 2011; Kamel et al., 2015).

The content of total AA in different samples of toasted FFSB was similar to those reported by Rostagno et al. (2011) (34\%). However, they were lower than those found by Valencia et al. (2009) and Ravindran et al. (2014), by 43 and $52 \%$, respectively, especially related to the concentration of methionine (Table 5).

The true ileal digestibility coefficient of essential AA of toasted FFSB samples was on average $87.90 \%$. These values were similar to those reported by Rostagno et al. (2011), which were $87.10 \%$. The inclusion of protease enhanced true ileal digestibility coefficient of essential AA $(\mathrm{P}<0.05)$ (Table 6).

On average, the inclusion of protease enhanced the digestibility of essential AA by $2.5 \%$. The higher variation was observed on digestibility coefficients of threonine, methionine and valine. Threonine is associated to the production of mucin, which in turn, stimulates the production of mucus by the gastrointestinal tract (Star et al., 2012). Fullfat soybeans contain some antinutritional factors, such as allergenic proteins. Also, it was observed low standardization on some FFSB, as samples 4 and 5. Probably, these factor influenced on results observed for threonine digestibility coefficient (up to $7.34 \%$ ). Valine is located in the inner part of the soybeans (Tavernari et al., 2013). It is digestibility increased, on average, by $4.10 \%$ due to inclusion of protease,

Table 4: Marginal means values of the full-fat soybean samples for nitrogen-corrected apparent metabolizable energy (AMEn) and the respective metabolization coefficient (CEMAn), for the first experiment.

\begin{tabular}{ccc}
\hline FFSB & AMEn & CAMEn \\
\hline Sample 1 & $2963 \mathrm{ab}$ & $57.29 \mathrm{ab}$ \\
Sample 2 & $3018 \mathrm{ab}$ & $59.18 \mathrm{ab}$ \\
Sample 3 & $3006 \mathrm{ab}$ & $57.40 \mathrm{ab}$ \\
Sample 4 & $2952 \mathrm{~b}$ & $63.54 \mathrm{ab}$ \\
Sample 5 & $3009 \mathrm{ab}$ & $56.70 \mathrm{ab}$ \\
Sample 6 & $3039 \mathrm{ab}$ & $58.25 \mathrm{ab}$ \\
Sample 7 & $3028 \mathrm{a}$ & $58.05 \mathrm{a}$ \\
Sample 8 & $3015 \mathrm{ab}$ & $59.02 \mathrm{ab}$ \\
Sample 9 & $3000 \mathrm{ab}$ & $57.78 \mathrm{ab}$ \\
\hline P-value & $<0.001$ & $<0.001$ \\
CV\% & 2.43 & 2.37 \\
\hline
\end{tabular}

FFSB = full-fat soybean; a-b Different letters in the same column differ by SNK test $(P<0.05)$; CV = Coefficient of variation. 
indicating greater FFSB protein degradation, as compared to samples that were not supplemented by the protease.

The increase in methionine availability is paramount. After all, it is the first limiting AA in diets for broilers with primary functions, such as donor of methyl groups, and together with cystine and cysteine, proper feathering (Baker et al., 1996). Methionine was detected at lower concentration of the total AA content in samples of FFSB analyzed in this study, and the role of protease was decisive for the increase of its respective coefficient up to $3.5 \%$. Furthermore, the concentration of methionine is influenced by the levels of lysine and arginine (Oliviera Neto et al., 2007), which also had their coefficients satisfactorily increased with the inclusion of 1.71 and $1.67 \%$ of protease, respectively.

The inclusion of monocomponent protease increased the CP digestibility of FFSB samples up to $4.35 \%$ (Table 7 ). Similar results were observed by preliminary studies working with monocomponent protease (Angel et al., 2011; Oxemboll et al., 2011; Freitas et al., 2011). This indicates greater degradation of antinutritional factors, improving other nutrients metabolism, increasing metabolizable of the diets. This was also found in in this study.
The mean true ileal digestibility coefficient of nonessential AA of FFSB was $84.34 \%$ higher than that found by Ravindran et al. (2014) (77.90\%). The inclusion of protease increased the digestibility of nonessential AA evaluated in this study $(\mathrm{P}<0.05)$ (Table 7). Of those, cystine, glycine and serine had their ratios increased by $6.15,4.29$ and $3.23 \%$, respectively.

Cystine is a sulfur AA that is present in pancreatic secretions and, the protease supplementation contribute to reduce cystine endogenous losses. Probably, this fact increases cystine digestibiliy coefficients. Also, glycine showed higher digestibility coefficient. The glycine composes mucoglicoproteins and participates in the metabolism of threonine (Ospina-Rojas et al., 2013). Thus, protease supplementation also reduced glycine endougenous losses, which increased its digestibility coefficientes. A similar response was observed by Angel et al. (2011) revealing that supplementation of a monocomponent protease improves endogenous enzymes activty, mainly peptidases. According Smith (2011) the supplementation of diets for broilers with serineproteases from Bacillus lincheniformis, as in this study, complements the action of endogenous enzymes such as

Table 5: Amino acid composition of toasted full-fat soybean samples (\% natural matter).

\begin{tabular}{cccccccccc}
\hline \multirow{2}{*}{ Amino acid } & \multicolumn{7}{c}{ Toasted full-fat soybean samples } \\
\cline { 2 - 9 } & 1 & 2 & 3 & 4 & 5 & 6 & 7 & 8 & 9 \\
\hline Lys & 2.15 & 2.27 & 2.44 & 2.47 & 2.17 & 2.12 & 2.44 & 2.11 & 2.27 \\
Thr & 1.23 & 1.84 & 1.34 & 1.38 & 1.21 & 1.22 & 1.32 & 1.28 & 1.31 \\
Met & 0.29 & 0.15 & 0.37 & 0.35 & 0.33 & 0.31 & 0.35 & 0.34 & 0.34 \\
Arg & 2.81 & 1.40 & 3.14 & 3.25 & 2.84 & 2.82 & 3.38 & 2.92 & 3.06 \\
His & 0.93 & 0.99 & 1.02 & 1.07 & 0.91 & 0.88 & 1.15 & 0.91 & 0.97 \\
Ile & 1.56 & 1.65 & 1.68 & 1.75 & 1.52 & 1.55 & 1.69 & 1.61 & 1.62 \\
Leu & 2.85 & 3.10 & 3.24 & 3.33 & 2.95 & 2.93 & 3.24 & 3.02 & 3.11 \\
Phe & 1.80 & 1.97 & 1.99 & 2.06 & 1.82 & 1.81 & 1.96 & 1.89 & 1.94 \\
Val & 1.77 & 0.39 & 1.95 & 2.01 & 1.77 & 1.74 & 1.92 & 1.88 & 1.84 \\
Cys & 0.46 & 0.49 & 0.46 & 0.57 & 0.43 & 0.43 & 0.55 & 0.53 & 0.45 \\
Ala & 1.64 & 2.16 & 1.82 & 1.84 & 1.62 & 1.64 & 1.86 & 1.72 & 1.75 \\
Asp & 3.35 & 3.62 & 4.25 & 3.68 & 2.80 & 3.44 & 3.43 & 3.41 & 3.51 \\
Glu & 6.37 & 6.95 & 7.55 & 7.19 & 5.93 & 6.46 & 6.89 & 6.58 & 6.78 \\
Gly & 1.72 & 1.84 & 1.92 & 2.03 & 1.79 & 1.79 & 2.06 & 1.88 & 1.89 \\
Ser & 1.77 & 1.98 & 1.96 & 1.98 & 1.76 & 1.72 & 1.92 & 1.79 & 1.92 \\
Tyr & 1.23 & 1.84 & 1.34 & 1.38 & 1.21 & 1.22 & 1.32 & 1.28 & 1.31 \\
Pro & 2.03 & 1.33 & 2.30 & 2.36 & 1.11 & 2.07 & 2.38 & 2.20 & 2.19 \\
\hline
\end{tabular}


pepsin and pancreatic proteases, increasing the solubility of proteins of the various dietary ingredients.

In addition, protease supplementation possibilities greater anti-nutritional factors degradation and higher aviability of AA for growth and muscle deposition. The supplementation of protease combined with diet formulation based on digestible AA may result in lower production costs and lower environmental impacts. According to Oxemboll et al. (2011) environmental pollution impacts can be reduced even with protease supplementation as "on top". However, this benefit is more evident, when the protein amount in the diet are reduced.

An effect of FFSB sample in related to the true digestibility coefficients of the main limiting AA for broilers, among the essential AA, non-essential AA and CP, and the sample 4 had the worst results (Table 8).

This indicates variability of whole soybean, especially related to soil type, cultivar planted, and the lack

Table 6: True ileal digestibility coefficients of essential amino acids of full-fat soybean samples, without or with protease supplementation.

\begin{tabular}{|c|c|c|c|c|c|c|c|c|c|c|}
\hline FFSB & $E$ & LYS & THR & MET & ARG & HIS & ILE & LEU & PHE & VAL \\
\hline \multirow{2}{*}{1} & whitout & 91.97 & 80.16 & 91.13 & 93.62 & 97.24 & 88.58 & 89.74 & 90.45 & 85.07 \\
\hline & with & 93.28 & 84.82 & 93.61 & 94.51 & 97.70 & 90.24 & 90.96 & 91.17 & 88.53 \\
\hline \multirow{2}{*}{2} & whitout & 92.87 & 82.42 & 93.47 & 93.81 & 97.45 & 89.47 & 91.18 & 91.40 & 86.70 \\
\hline & with & 94.59 & 86.68 & 95.09 & 95.45 & 98.41 & 91.71 & 93.03 & 93.11 & 90.28 \\
\hline \multirow{2}{*}{3} & without & 92.32 & 80.73 & 88.91 & 92.35 & 97.40 & 87.34 & 88.55 & 89.44 & 83.45 \\
\hline & with & 93.81 & 85.44 & 91.90 & 93.86 & 98.11 & 90.48 & 92.24 & 92.00 & 87.64 \\
\hline \multirow{2}{*}{4} & without & 91.27 & 74.01 & 89.33 & 92.34 & 93.37 & 84.65 & 85.60 & 87.37 & 82.29 \\
\hline & with & 92.93 & 78.81 & 92.41 & 94.42 & 95.13 & 86.83 & 87.87 & 89.67 & 84.90 \\
\hline \multirow{2}{*}{5} & without & 91.64 & 80.34 & 88.54 & 91.40 & 92.86 & 84.08 & 86.43 & 86.10 & 81.29 \\
\hline & with & 93.69 & 87.68 & 94.69 & 93.64 & 94.48 & 88.36 & 89.90 & 89.57 & 86.30 \\
\hline \multirow{2}{*}{6} & without & 91.25 & 81.18 & 93.81 & 93.01 & 92.73 & 88.10 & 88.55 & 89.20 & 85.05 \\
\hline & with & 93.07 & 86.73 & 97.10 & 95.36 & 94.88 & 91.04 & 91.31 & 91.97 & 88.60 \\
\hline \multirow{2}{*}{7} & without & 92.35 & 80.59 & 94.75 & 93.22 & 94.14 & 87.11 & 86.75 & 88.49 & 84.43 \\
\hline & with & 93.75 & 84.46 & 95.76 & 94.44 & 94.89 & 89.25 & 90.09 & 90.44 & 86.93 \\
\hline \multirow{2}{*}{8} & without & 84.24 & 70.04 & 82.68 & 88.20 & 80.70 & 79.23 & 85.03 & 81.68 & 75.45 \\
\hline & with & 85.91 & 74.23 & 86.09 & 89.34 & 82.82 & 81.83 & 87.08 & 83.88 & 79.03 \\
\hline \multirow{2}{*}{9} & without & 91.78 & 84.77 & 92.95 & 93.92 & 83.36 & 88.10 & 89.22 & 89.75 & 84.13 \\
\hline & with & 92.99 & 87.97 & 93.10 & 94.98 & 86.44 & 89.82 & 90.43 & 90.30 & 87.68 \\
\hline \multirow{2}{*}{ Mean } & without & $91.08 \mathrm{~b}$ & $79.36 b$ & $90.62 b$ & $92.43 b$ & $92.14 b$ & $86.30 \mathrm{~b}$ & $87.90 \mathrm{~b}$ & $88.21 \mathrm{~b}$ & $83.10 \mathrm{~b}$ \\
\hline & with & $92.67 a$ & $84.10 a$ & $93.31 a$ & $94.00 a$ & $93.65 a$ & $88.84 a$ & $90.33 a$ & $90.24 a$ & $86.66 a$ \\
\hline$C V(\%)$ & & 1.36 & 4.02 & 2.43 & 1.25 & 1.75 & 2.26 & 2.04 & 1.97 & 2.6 \\
\hline \multicolumn{11}{|c|}{$P$ - value } \\
\hline \multicolumn{2}{|c|}{$\mathrm{FFSB}^{1}$} & $<.001$ & $<.001$ & $<.001$ & $<.001$ & $<.001$ & $<.001$ & $<.001$ & $<.001$ & $<.001$ \\
\hline \multicolumn{2}{|c|}{$E$} & $<.001$ & $<.001$ & $<.001$ & $<.001$ & $<.001$ & $<.001$ & $<.001$ & $<.001$ & $<.001$ \\
\hline \multicolumn{2}{|c|}{ FFSBXE } & 0.996 & 0.886 & 0.424 & 0.639 & 0.446 & 0.787 & 0.513 & 0.460 & 0.910 \\
\hline
\end{tabular}

FFSB = full-fat soybeans samples; $E$ = enzyme; FFSBxE = interaction of factors FFSB and E; $a, b$ Different letters in the same column differ by SNK test $(\mathrm{P}<0.05)$; $\mathrm{CV}=$ Coefficient of variation. ${ }^{1}$ The marginal mean values of FFSB samples are presented in Table 8. 
of standardization in the same type of thermal processing. Therefore, the use of more effective thermal methods can reduce the variability of the quality of FFSB. According Alsaftli et al. (2015) more refined thermal processes such as extrusion of FFSB, favor the use of nutrients by birds, with significant gains in performance and carcass characteristics.

The values of digestible AA of different samples of FFSB in this study were similar to those found by Rostagno et al. (2011) and Ravindran et al. (2014), except for methionine values, which were lower (Table 9). Methionine is the principal limiting AA in broiler diets, and the most expensive AA. Therefore, when using the toasted FFSB replacing soybean meal as a protein source, the larger synthetic methionine supplementation can be needed to meet the broiler nutritional requirements.

The results of this study suggest that protease supplementation is a good alternative to the formulation of diets for poultry. Protease supplementation can be

Table 7: True ileal digestibility coefficients of nonessential amino acids and crude protein of full-fat soybean samples, without or with protease supplementation.

\begin{tabular}{|c|c|c|c|c|c|c|c|c|c|c|}
\hline FFSB & $E$ & CYS & ALA & ASP & GLU & GLY & SER & TYR & PRO & $\mathrm{CP}$ \\
\hline \multirow{2}{*}{1} & whitout & 71.00 & 86.61 & 89.97 & 92.73 & 80.87 & 85.79 & 88.25 & 88.00 & 86.08 \\
\hline & with & 73.97 & 88.18 & 91.23 & 93.84 & 82.09 & 87.64 & 89.34 & 88.13 & 88.47 \\
\hline \multirow{2}{*}{2} & whitout & 74.16 & 88.24 & 91.24 & 93.46 & 83.30 & 88.39 & 89.81 & 89.53 & 89.48 \\
\hline & with & 77.37 & 90.90 & 93.99 & 95.19 & 84.96 & 90.42 & 91.89 & 91.21 & 91.16 \\
\hline \multirow{2}{*}{3} & without & 74.39 & 86.29 & 90.50 & 92.19 & 83.06 & 86.35 & 88.13 & 80.05 & 88.93 \\
\hline & with & 76.74 & 88.90 & 92.87 & 94.17 & 87.39 & 91.13 & 92.02 & 90.96 & 90.94 \\
\hline \multirow{2}{*}{4} & without & 61.52 & 83.58 & 89.87 & 91.97 & 76.11 & 84.15 & 82.86 & 81.96 & 85.47 \\
\hline & with & 70.01 & 86.25 & 91.75 & 93.67 & 81.25 & 87.53 & 85.85 & 86.24 & 88.17 \\
\hline \multirow{2}{*}{5} & without & 84.50 & 83.59 & 89.44 & 91.28 & 76.96 & 83.04 & 85.86 & 84.33 & 86.93 \\
\hline & with & 91.65 & 87.29 & 91.92 & 93.38 & 80.74 & 87.53 & 90.83 & 88.78 & 90.87 \\
\hline \multirow{2}{*}{6} & without & 78.94 & 84.13 & 90.65 & 92.07 & 75.14 & 86.03 & 89.24 & 83.47 & 87.64 \\
\hline & with & 85.66 & 87.53 & 92.83 & 94.04 & 81.31 & 89.43 & 92.18 & 88.86 & 90.32 \\
\hline \multirow{2}{*}{7} & without & 75.66 & 84.39 & 91.40 & 92.75 & 77.01 & 84.49 & 88.45 & 85.28 & 87.70 \\
\hline & with & 80.63 & 86.65 & 92.53 & 93.95 & 80.75 & 86.04 & 90.13 & 87.90 & 91.15 \\
\hline \multirow{2}{*}{8} & without & 58.27 & 76.05 & 82.47 & 86.15 & 64.89 & 75.59 & 83.00 & 77.39 & 79.70 \\
\hline & with & 61.19 & 78.14 & 84.16 & 87.74 & 68.14 & 77.89 & 84.45 & 79.47 & 82.36 \\
\hline \multirow{2}{*}{9} & without & 87.99 & 86.33 & 91.24 & 91.97 & 82.01 & 88.24 & 91.99 & 88.36 & 88.17 \\
\hline & with & 93.02 & 88.03 & 93.06 & 93.04 & 84.18 & 89.93 & 92.65 & 89.05 & 91.37 \\
\hline \multirow{2}{*}{ Mean } & without & $74.05 b$ & $84.36 b$ & $89.64 b$ & $91.62 b$ & $77.71 b$ & $84.67 b$ & $87.51 \mathrm{~b}$ & $85.15 b$ & $86.79 b$ \\
\hline & with & $78.91 a$ & $86.87 a$ & $91.59 a$ & $93.22 \mathrm{a}$ & $81.20 a$ & $87.50 a$ & $89.93 a$ & $87.84 a$ & $89.43 a$ \\
\hline \multirow[t]{2}{*}{ CV(\%) } & & 5.20 & 2.54 & 2.13 & 1.41 & 3,92 & 2.62 & 2.14 & 2.38 & 2.01 \\
\hline & \multicolumn{10}{|c|}{$P$-value } \\
\hline $\mathrm{FFSB}^{1}$ & & $<.001$ & $<.001$ & $<.001$ & $<.001$ & $<.001$ & $<.001$ & $<.001$ & $<.001$ & $<.001$ \\
\hline E & & $<.001$ & $<.001$ & $<.001$ & $<.001$ & $<.001$ & $<.001$ & $<.001$ & $<.001$ & $<.001$ \\
\hline FFSBXE & & 0.383 & 0.937 & 0.974 & 0.960 & 0.497 & 0.432 & 0.693 & 0.973 & 0.883 \\
\hline
\end{tabular}

FFSB = full-fat soybeans samples; $E$ = enzyme; FFSBXE = interaction of factors FFSB and E; CP = crude protein; $a$, b Different letters in the same column differ by SNK test $(P<0.05)$; $C V$ = Coefficient of variation. ${ }^{1}$ The marginal mean values of the FFSB samples are presented in Table 8. 
Table 8: Marginal mean values of the full-fat soybean samples for the true ileal digestibility coefficients of main limiting amino acids, essential amino acid, non-essential and crude protein.

\begin{tabular}{ccccccc}
\hline FFSB & MET & \multicolumn{1}{c}{ LYS } & THR & TIDCEA & TIDCNEA & TIDCCP \\
\hline 1 & $92.37 \mathrm{bc}$ & $92.62 \mathrm{ab}$ & $82.49 \mathrm{~b}$ & $91.03 \mathrm{ab}$ & $88.93 \mathrm{abc}$ & $87.28 \mathrm{bc}$ \\
2 & $92.48 \mathrm{ab}$ & $93.73 \mathrm{a}$ & $84.55 \mathrm{ab}$ & $92.26 \mathrm{a}$ & $90.94 \mathrm{a}$ & $90.32 \mathrm{a}$ \\
3 & $90.40 \mathrm{c}$ & $93.07 \mathrm{ab}$ & $83.08 \mathrm{ab}$ & $91.64 \mathrm{ab}$ & $90.92 \mathrm{ab}$ & $89.94 \mathrm{a}$ \\
4 & $84.39 \mathrm{~d}$ & $85.07 \mathrm{c}$ & $72.14 \mathrm{~d}$ & $82.91 \mathrm{e}$ & $80.38 \mathrm{~d}$ & $81.03 \mathrm{~d}$ \\
5 & $91.61 \mathrm{c}$ & $92.66 \mathrm{ab}$ & $84.01 \mathrm{ab}$ & $88.76 \mathrm{~cd}$ & $88.44 \mathrm{bc}$ & $88.94 \mathrm{abc}$ \\
6 & $95.45 \mathrm{a}$ & $92.16 \mathrm{~b}$ & $83.96 \mathrm{ab}$ & $90.45 \mathrm{~b}$ & $89.01 \mathrm{abc}$ & $88.98 \mathrm{ab}$ \\
7 & $90.87 \mathrm{c}$ & $92.10 \mathrm{~b}$ & $76.41 \mathrm{c}$ & $88.14 \mathrm{~d}$ & $87.58 \mathrm{c}$ & $86.82 \mathrm{~b}$ \\
8 & $95.25 \mathrm{a}$ & $93.05 \mathrm{ab}$ & $82.52 \mathrm{ab}$ & $89.92 \mathrm{bcd}$ & $88.67 \mathrm{bc}$ & $89.93 \mathrm{a}$ \\
9 & $93.03 \mathrm{abc}$ & $92.39 \mathrm{ab}$ & $86.37 \mathrm{a}$ & $90.16 \mathrm{bc}$ & $90.15 \mathrm{ab}$ & $89.77 \mathrm{a}$ \\
\hline P-value & $<.001$ & $<.001$ & $<.001$ & $<.001$ & $<.001$ & $<.001$ \\
CV (\%) & 2.73 & 1.63 & 3.83 & 1.58 & 2.03 & 2.09 \\
\hline
\end{tabular}

a-b Different letters in the same column differ by SNK test $(\mathrm{P}<0.05) ; \mathrm{FFSB}=$ full-fat soybeans; TIDCAE $=$ true ileal digestibility coefficient amino acid essential; TIDCANE = true ileal digestibility coefficient amino acid non essential; TIDCCP = true ileal digestibility coefficient of $\mathrm{CP} ; \mathrm{CV}=$ Coefficient of variation.

Table 9: True digestible amino acids (AASD) of toasted full-fat soybean samples (\% natural matter).

\begin{tabular}{cccccccccc}
\hline \multirow{2}{*}{ AASD } & \multicolumn{7}{c}{ Toasted full-fat soybean samples } \\
\cline { 2 - 9 } & 1 & 2 & 3 & 4 & 5 & 6 & 7 & 8 & 9 \\
\hline Lys & 1.98 & 2.11 & 2.25 & 2.25 & 1.99 & 1.93 & 2.25 & 1.78 & 2.08 \\
Thr & 1.03 & 1.45 & 1.16 & 1.06 & 1.05 & 1.01 & 1.08 & 0.94 & 1.16 \\
Met & 0.26 & 0.14 & 0.33 & 0.31 & 0.29 & 0.29 & 0.33 & 0.28 & 0.32 \\
Arg & 2.63 & 1.31 & 2.90 & 2.99 & 2.59 & 2.62 & 3.15 & 2.57 & 2.87 \\
His & 0.90 & 0.96 & 0.99 & 0.99 & 0.84 & 0.82 & 1.08 & 0.73 & 0.81 \\
Ile & 1.38 & 1.48 & 1.47 & 1.48 & 1.28 & 1.36 & 1.47 & 1.27 & 1.43 \\
Leu & 2.56 & 2.82 & 2.87 & 2.85 & 2.55 & 2.59 & 2.81 & 2.57 & 2.77 \\
Phe & 1.63 & 1.80 & 1.78 & 1.80 & 1.57 & 1.61 & 1.73 & 1.54 & 1.74 \\
Val & 1.50 & 0.34 & 1.63 & 1.65 & 1.44 & 1.48 & 1.62 & 1.42 & 1.55 \\
Cys & 0.33 & 0.36 & 0.34 & 0.35 & 0.36 & 0.34 & 0.42 & 0.31 & 0.39 \\
Ala & 1.42 & 1.90 & 1.57 & 1.54 & 1.35 & 1.38 & 1.57 & 1.31 & 1.51 \\
Asp & 3.01 & 3.30 & 3.85 & 3.31 & 2.50 & 3.12 & 3.13 & 2.81 & 3.20 \\
Glu & 5.91 & 6.49 & 6.96 & 6.61 & 5.41 & 5.95 & 6.39 & 5.67 & 6.23 \\
Gly & 1.39 & 1.53 & 1.59 & 1.54 & 1.38 & 1.34 & 1.59 & 1.22 & 1.55 \\
Ser & 1.52 & 1.75 & 1.69 & 1.67 & 1.46 & 1.48 & 1.62 & 1.35 & 1.69 \\
Tyr & 1.08 & 1.65 & 1.18 & 1.14 & 1.04 & 1.09 & 1.17 & 1.06 & 1.20 \\
Pro & 1.79 & 1.19 & 2.02 & 1.93 & 1.78 & 1.73 & 2.03 & 1.70 & 1.93 \\
\hline
\end{tabular}


used in order to optimize protein and energy utilization and to provide greater availability of AA in broiler diets formulated with FFSB. However, it is necessary further studies to evaluate the values of AMEn and AA of toasted FFSB as well as the possible interactions with exogenous enzymes to increase the availability of nutrients required by the broilers.

\section{CONCLUSIONS}

The average values of AMEn and their respective CAMEn of toasted full-fat soybeans were $3207 \mathrm{kcal} /$ $\mathrm{kg}$ and $62.57 \%$, respectively. The average coefficients of true ileal digestibility of crude protein, essential and nonessential amino acids were $86.79,87.90$ and $84.34 \%$, respectively. The supplementation with protease in diets for broilers, formulated with toasted full-fat soybean, enhanced the values of AMEn and CAMEn, improved the digestibility of crude protein, and the availability of essential and nonessential amino acids. Thus, it is recommended the supplementation of a monocomponent protease in order to optimize nutrient utilization, particularly proteins and amino acids, and to alleviate the adverse effects of inadequate thermal treatment of toasted full-fat soybeans.

\section{REFERENCES}

ALSAFTLI, Z. A.; AL-SAADI, M. A.; SUBUH, A. M. Effect of using extruded full-fat soybean on performance and carcass characteristics in female turkeys. Asian Journal of Animal Sciences. 9(5):198-207, 2015.

ASSOCIAÇÃO NACIONAL DOS FABRICANTES DE RAÇÕES ANFAR. Compêndio Brasileiro de Alimentação Animal: Métodos Analíticos. 2005. 204 p.

ANGEL, C. R. et al. Effects of a monocomponent protease on performance and protein utilization in 7- to 22-day-old broiler chickens. Poultry Science. 90(10):2281-2286, 2011.

ARABA, M.; DALE, N. M. Evaluation of protein solubility as an indicator of overprocessing of soybean meal. Poultry Science. 69(8):76-82, 1990.

ASSOCIATION OF OFFICIAL AGRICULTURAL CHEMISTS - AOAC. Official methods of the Association of the Agricultural Chemists. 16. ed. Washington, DC, 1995. v. 2, 1094p.

BAKER, D. H. et al. Sulfur amino acid requirement and cystine replacement value of broiler chicks during the period three to six weeks post-hatching. Poultry Science. 75(6):737-42, 1996.
CAFÉ, M. B. et al. Composição e digestibilidade dos aminoácidos das sojas integrais processadas para aves. Revista Brasileira de Ciência Avícola. 2(1):59-66, 2000.

CARVALHO, A. A. et al. Digestibilidade aparente de dietas e metabolismo de frangos de corte alimentados com dietas contendo soja integral processada. Ciência Rural. 38(2):477-483, 2008.

CLARKE, E.; WISEMAN, J. Effects of variability in trypsin inhibitor content of soya bean meals on true and apparent ileal digestibility of amino acids and pancreas size in broiler chicks. Animal Feed Science and Technology. 121(2):125138, 2005.

COSTA, E. M. S. et al. Grão integral processado e coprodutos da soja em dietas para frangos de corte. Revista Ciência Agronômica. 46(4):846-854, 2015.

FREITAS, E. R. et al. Efeito do processamento da soja integral sobre a energia metabolizável e a digestibilidade dos aminoácidos para aves. Revista Brasileira de Zootecnia. 34(6):1938-1949, 2005.

FREITAS, D. M. et al. Performance and nutrient utilization of broilers fed diets supplemented with a novel monocomponent protease. The Journal of Applied Poultry Research. 20(3):322-334, 2011.

FRU-NJI, F. et al. A feed serine protease improves broiler performance and increases protein and energy digestibility. Japan Poultry Science. 48(4):239-246, 2011.

GHAZI, S. et al. The potential for the improvement of the nutritive value of soya-bean meal by different proteases in broiler chicks and broiler cockerels. British Poultry Science. 43(1):70-77, 2002.

GRAHAN, K. K. et al. The effect of enzyme treatment of soybean meal on oligosaccharide disappearance and chick growth performance. Poultry Science. 81(7):1014-1019, 2002.

GOMES, P. C. et al. Valores de aminoácidos digestíveis de alimentos para aves. Revista Brasileira de Zootecnia. 39(6):1259-1265, 2010

JOSLYN, M. A. Methods in Food Analysis: Physical, Chemical, and Instrumental Methods of Analysis. 2.ed. Academic Press, New York, 1970. 845p.

KAMEL, N. F. et al. Effects of a Monocomponent Protease on Performance Parameters and Protein Digestibility in Broiler Chickens. Agriculture and Agricultural Science Procedia. 6(1):216-225, 2015. 
LEMME, A.; RAVINDRAN, V.; BRYDEN, W. L. Ileal digestibility of amino acids in feed ingredients for broilers. World's Poultry Science Journal. 60(4):423-438, 2004.

MATIAS, C. F. Q. et al. Efeito da protease sobre o coeficiente de metabolizabilidade dos nutrientes em frangos de corte. Arquivo Brasileiro de Medicina Veterinária e Zootecnia. 67(2):492-498, 2015.

MATTERSON, L. D. et al. The metabolizable energy of feeds ingredient for chickens. Storrs: The University of Connecticut-Agricultural Experiment Station, 1965. 11p. (Research Peport, 7).

NCOBELA, C. N.; CHIMONYO, M. Potential of using nonconventional animal protein sources for sustainable intensification of scavenging village chickens: A review. Animal Feed Science and Technology. 208(10):1-11, 2015.

NUNES, R. V. et al. Valores energéticos de subprodutos de origem animal para aves. Revista Brasileira de Zootecnia. 34(4):1217-1224, 2005.

NUNES, R. V. et al. Avaliação nutricional e energética da soja integral desativada para aves. Revista Caatinga. 28(2):143151, 2015.

OLIVEIRA NETO, A. R. et al. Níveis de metionina + cistina total para frangos de corte de 22 a 42 dias de idade mantidos em ambiente termoneutro. Revista Brasileira de Zootecnia. 36(5):1359-1364, 2007.

OSPINA-ROJAS, I. C. et al. Supplemental glycine and threonine effects on performance, intestinal mucosa development, and nutrient utilization of growing broiler chickens. Poultry Science. 92(10):2724-2731, 2013.

OXEMBOLL, K. M.; PONTOPPIDAN, K.; FRU-NJI, F. Use of a protease in poultry feed offers promising environmental benefits. International Journal of Poultry Science. 10(11):842-848, 2011.

PARSONS, C. M. et al. Soybean protein solubility in potassium hydroxide: An in vitro test of in vivo protein quality. Journal Animal Science. 69(7):2918-2924, 1991.
RAVINDRAN, V.; ABDOLLAHI, M.; BOOTWALLA, S. Nutrient analysis, apparent metabolisable energy and ileal amino acid digestibility of full fat soybean for broilers. Animal Feed Science and Technology. 197(8):233-240, 2014.

ROCHA, C. et al. The effect of raw and roasted soybeans on intestinal health, diet digestibility, and pancreas weight of broilers. The Journal of Applied Poultry Research. 23(1):71-79, 2014.

ROSTAGNO, H. S. et al. Tabelas brasileiras para aves e suínos: Composição de alimentos e exigências nutricionais, 3.ed. Viçosa: UFV, 2011, 252p.

SISTEMA PARA ANÁLISES ESTATÍSTICAS - SAEG. Versão 9.1: Fundação Arthur Bernardes - UFV, Viçosa, 2007.

SAKOMURA, N. K.; ROSTAGNO, H. S. Métodos de pesquisa em nutrição de monogástricos. Jaboticabal: Funep, 2007, 283p.

SILVA, D. J.; QUEIROZ, A. C. Análise de Alimentos: métodos químicos e biológicos. 3. ed. Viçosa: UFV, 2002, 235p.

SMITH, A. Using proteases in broiler diets - careful selection is key. International Poultry Production. 19(7):15-17, 2011.

STAR, L. et al. Threonine requirement of broiler chickens during subclinical intestinal Clostridium infection. Poultry Science. 91(3):643-652, 2012.

TAVERNARI, F. C. et al. Valine needs in starting and growing Cobb (500) broilers. Poultry Science. 92(1):151-157, 2013.

VALENCIA, D. G. et al. Influence of micronization (fine grinding) of soya bean meal and full-fat soya bean on the ileal digestibility of amino acids for broilers. Animal Feed Science and Technology. 180(4):238-248, 2009.

YU, B. et al. Effects of enzyme inclusion in a maize-soybean diet on broiler performance. Animal Feed Science and Technology. 134(4):283-294, 2007.

ZILIC, S. M. et al. Characterization of proteins from kernel of different soybean varieties. Journal of the Science of Food and Agriculture. 91(1):60-67, 2011. 